
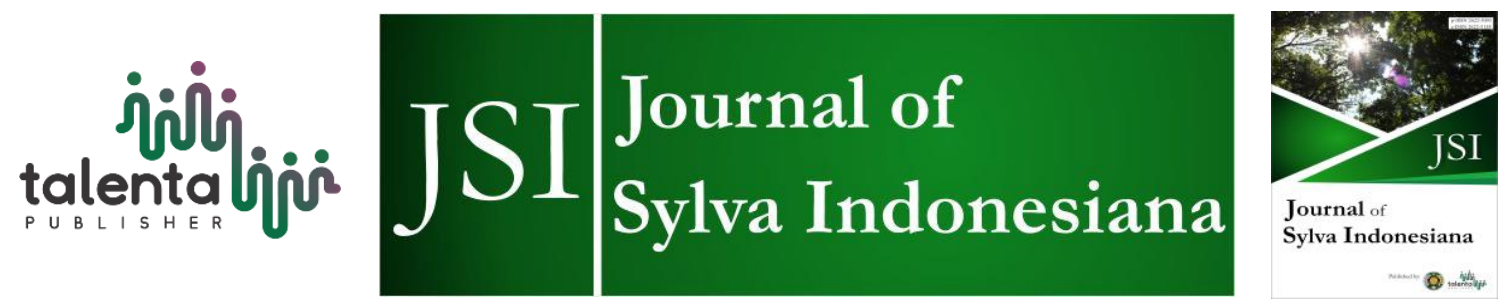

\title{
The Application of Silviculture Techniques on White Jabon (Neolamarckia cadamba Miq) by The Farmers of Community Forest in Konawe Regency, Southeast Sulawesi
}

\author{
Faisal Danu Tuheteru ${ }^{1}$, Husna $^{2}$, Inggrik Valentin Rare ${ }^{3}$, Asrianti Arif $^{4}$, Albasri $^{5}$ \\ 1,2,3,4,5 Forestry Department, Faculty of Forestry and Environmental Sciences, Halu Oleo University
}

\begin{abstract}
The objective of this research was to determine of silviculture techniques of white jabon (Neolamarckia cadamba) that are applied by farmers in Konawe. This study was conducted at four location those were Sub District of Unaaha-District of Unaaha, Wawoone Village, Tetemotaha Village, and Langgonawe Village of Wonggeduku District, Konawe, Southeast Sulawesi Province, Indonesia. The research activities included of site selection, interviews with owners, and Jabon stands inventory. The results showed that farmers in Konawe planted white Jabon (N. cadamba Miq.) without formal training on silviculture technique. The farmers get the knowledge of white jabon cultivation through books, internet access, and other farmers. The silviculture techniques were applied by farmers through seed preparation, land preparation, planting, and maintenance activities including replanting, weeding, fertilizing application, pest and disease controlling, and thinning.
\end{abstract}

Keyword: Growth, Konawe, Neolamarkia cadamba Miq., Silvicultural techniques

Received 03 May 2019| Revised 09 July 2019| Accepted 15 August 2019

\section{Introduction}

White jabon (Neolamarckia cadamba Miq.) belongs to member of Rubiaceae family and widely distributed in some province in Indonesia [1]. White jabon [Neolamarckia cadamba Miq., syn. Neolamarckia chinensis (Lamk.) A. Rich. Ex. Walp.] originated from South and Southeast Asia [2] and distributed in Sumatra, West Java, East Java, East Kalimantan, South Kalimantan, all of Sulawesi, West Nusa Tenggara and Papua [3].

White jabon tree has a straight and cylindrical trunk, able to growth up to $45 \mathrm{~m}$ with a branch-free trunk reaching $30 \mathrm{~m}$, and breast height diameter of 100-160 $\mathrm{cm} \mathrm{[1].} \mathrm{White} \mathrm{jabon} \mathrm{has} \mathrm{a} \mathrm{wide} \mathrm{of}$

\footnotetext{
*Corresponding author at: Halu Oleo University, JI. Mayjen S. Parman, Lahundape, Kendari 93121, Southeast Sulawesi, Indonesia

E-mail address: fdtuheteru1978@gmail.com
}

Copyright (c) 2019 Published by Talenta Publisher

p-ISSN: 2622-5093 e-ISSN: 2622-5158 DOI : 10.32734/jsi.v2i2.993

Journal Homepage: https://talenta.usu.ac.id/Jsi 
growing habitat but grows well at altitude of 23 to $628 \mathrm{~m}$ above sea level [4]. It also can grow on various types of soils, even on ex-mining land [1].

White jabon is an ideal tree species and has high prospects for plantation forest and reforestation in Indonesia [2]. The wood of white jabon can be utilize for matches, pulp, and in particular for lightweight constructions [1]. The trees are now widely planted both on small and large scales in several regions throughout Indonesia, such as South Kalimantan [5], [2], Central Java in Banjarnegara [6], Pemalang [7], Cilacap [8], West Java [9] in Cianjur [10], Purwakarta [11], Pakenjeng in Garut Regency [12], and East Java in Madiun [13]. Information of jabon stands in Southeast Sulawesi is still limited. The available data only in Wombulu Village, Buton Regency around of 24 ha [14] and in Wawoone Village, Konawe Regency around of 2 ha [15]. In general, Jabon can be reproduced either generatively through seeds [4] and vegetatively, namely tissue culture, shoot and stem cuttings or by stump and extraction [1].

Silviculture techniques are meant to treat of forests in an effort to maintain and increase its productivity, through seed handling, nursery, land preparation, planting, and maintenance activities. Studies related to white jabon silviculture techniques have been conducted in Indonesia, e.g. South Kalimantan [5] and Java [8], [16]. However, there is no information about it aplication in Southeast Sulawesi. Therefore, our study aimed to determine silviculture techniques conducted by farmers of the community forest in Konawe Regency, Southeast Sulawesi Province.

\section{Materials and Method}

\subsection{Materials}

Materials used in this study were Tally sheet and questionnaire. The tool used in this study were hypsometer, meter tape, roller meter, raffia, GPS (Global Positioning System), and digital cameras.

\subsection{Method}

\section{A. Site Selection}

Site selection was determined by purposive sampling, with considering the existence or ownership of community forest, this research was carried out in several locations in Konawe Regency, Southeast Sulawesi.

\section{B. Interview}

The interview regarding silviculture practice on white jabon was done using the structured interview technique, which means data were collected through question and answer to respondents directly based on interview guidelines. The main objective of the interview was to determine the socioeconomic conditions of jabon farmers, planting motivation, and silviculture techniques. The interview 
material for silviculture techniques consisted of components of propagation, planting components in land preparation, planting holes and spacing, and maintenance components for weeding, fertilizing, pruning, pest protection, and thinning. Four respondents were interviewed.

\section{Stand Inventory}

The purpose of jabon stand inventory was to evaluate and analyze of jabon stand quality. Inventory was conducted through measuring height, diameter, and age. Jabon stand inventory was carried out using a random sampling methods. This method better describe the specific database of white Jabon stand (Jinwo, 2013).

\section{Growth of White Jabon}

The growth of white Jabon was estimated based on the measurement of temporary sample plot. Number of plots was obtained from calculation of community forest area, sampling intensity, and sampling area. Community forest area on the research site was 4.9 ha. The dimension measurement of the jabon stand was calculated by measuring the breast height diameter and total height with form factor number of 0.47 [2]. The number of plots was calculated using the following formulas:

$$
\text { Sampling area }=\text { sampling intensity } x \text { community forest area }
$$

$$
\text { Number of plot }=\frac{\text { sampling area }}{(10 \times 20) m}
$$

The tree volume estimation (Vt) was calculated using the formula as follows:

$$
\mathrm{Vt}=0.25 \times 3.14 \times d 2 \times t \times 0.47
$$

Description:

$\mathrm{Vp} \quad=$ tree volume $\left(\mathrm{m}^{3}\right)$

$\mathrm{d} \quad=$ diameter

$\mathrm{h}=$ total height

$0.47=$ form factor for jabon species

The volume of stand and volume of stands per ha were calculated using the formula:

$$
\text { Vstand }=\sum_{\mathrm{t}=1}^{\mathrm{N}} \mathrm{V} 1
$$

Description:

$$
\begin{array}{ll}
\text { Vstand } & =\text { volume of stand in the area }\left(\mathrm{m}^{3}\right) \\
\text { Vi } & =\text { measured volume of } \mathrm{i}\left(\mathrm{m}^{3}\right)
\end{array}
$$


$\mathrm{N}$

$=$ number of trees in the stand

$$
\mathrm{V} \text { stand } / \text { ha }=\frac{\sum_{\mathrm{t}=1}^{\mathrm{N}} \mathrm{V} 1}{\text { Plot area }}
$$

Description:

$$
\begin{aligned}
& \text { Vstands/ha }=\text { volume of stand per ha }\left(\mathrm{m}^{3} / \mathrm{ha}\right) \\
& \mathrm{Vi} \quad=\text { measured volume of } \mathrm{i}\left(\mathrm{m}^{3}\right) \\
& \mathrm{N}=\text { number of trees in the stand }
\end{aligned}
$$

\section{Results and Discussion}

\subsection{The Farmers of Jabon}

The information about research respondents or farmers in community forests is presented in Table 1. There are four farmers in Konawe Regency distributed in four locations those were: Unaaha, Langgonawe, Wawoone, and Tetemotaha Villages. The average age of farmers was over 55 years with the education level was varied from high school until bacelor degree. Result of interview showed that most of farmers did not get special training and guidance on silvicultural techniques for jabon.

\begin{tabular}{|c|c|c|c|c|c|c|}
\hline Location & Name & Age & Education & $\begin{array}{c}\text { Silviculture } \\
\text { Training }\end{array}$ & $\begin{array}{c}\text { Cultivation } \\
\text { Information }\end{array}$ & Motivation \\
\hline Unaaha & $\begin{array}{l}\text { Kerja } \\
\text { Tarigan }\end{array}$ & 58 & Bachelor & No & Internet & Economy \\
\hline Langgonawe & Abdul Ginal & 57 & Bachelor & No & Other farmers & Economy \\
\hline Wawoone & $\begin{array}{l}\text { Subowo } \\
\text { Santoso }\end{array}$ & 66 & $\begin{array}{l}\text { High } \\
\text { School }\end{array}$ & No & Book & Economy \\
\hline Tetemotaha & $\begin{array}{l}\text { Wayan } \\
\text { Suheda }\end{array}$ & 64 & Diploma & No & Book & Economy \\
\hline
\end{tabular}
The knowledge about jabon cultivation was obtained from books, internet, and other farmers. In general, the economic factor was the main motivation for farmers to plant jabon.

Table 1 Characteristic and Motivation of Jabon Farmers

\subsection{Silviculture Techniques}

\section{A. Procurement of Seeds}

Farmers cultivated the plant from seed by acquiring new seedling naturally grown from the tree or from other farmers. Seeds were collected directly from the stand, then were manually extracted, were separated from the flesh and were mixed with husk ash. This mixture then was sprinkled on seedbed containing soil and sand with a ratio of 2:1 and was covered with jute bag for one week. After the seeds fully germinated, they were moved to polybags until each germinate sprout has 2-4 leaves. The sprout emerge indicating ability for planting. The jabon seedling price was IDR 5,000 with the height $60 \mathrm{~cm}$. The ideal height for a seedling to be planted is at a range of $20-60 \mathrm{~cm}$. 


\section{B. Land Preparation and Planting}

The land was cleared and prepared manually using hoes, machetes, sickles, and grass spray (Table 2). Two farmers, namely Mr. Tarigan and Mr. Subowo, cleared their lands with a total slash system because the areas were covered with shrubs. Mr. Wayan had his land overgrown by shrubs, but they were not too tall or dense. Therefore, he sprayed Polaris 240 AS herbicide to clear his land. The land owned by Mr. Abdul was a former plantation, for this reason, all he had to do was clearing up the area circling the planting holes. The costs for land clearing were varied; for a 2 hectares area, Mr. Subowo and Mr. Wayan spent IDR 350,000 and IDR 500,000, respectively. Two other farmers cleared the land on their own, therefore they paid no expense for this activity.

Generally, the farmers used spacing 3 x $3 \mathrm{~m}$ (Mr. Wayan), 4 x $4 \mathrm{~m}$ (Mr. Tarigan and Mr. Subowo), and 4 × $5 \mathrm{~m}$ (Mr. Abdul). The planting hole size was $10 \times 15 \times 10 \mathrm{~cm}$ to $30 \times 30 \times 40 \mathrm{~cm}$ (Table 2). For basic fertilizer Mr. Abdul and Mr. Subowo added $0.5 \mathrm{~kg}$ of organic fertilizer per plant, while Mr. Wayan added $100 \mathrm{~kg}$ NPK per hectare. To prevent pests, Mr. Abdul and Mr. Subowo applied furadan.

\section{Maintenance}

The planting activity was followed by several plant maintaining, i.e. replacing, weeding, fertilizing, thinning, and pests and disease prevention. Fertilizing was conducted after the trees reach six months to two years, using organic and inorganic fertilizers, namely manure, NPK, and urea (Table 3). Farmers of Tetemoha Village, Mr. Wayan spend IDR 1,000,000 for two fertilizing activities. Whereas, Wawoone Village farmers, Mr. Subono, conducted one-time fertilizing and spent only IDR 200,000 .

The mortality rate on Mr. Wayan's land reached 30\%, thus he had to replace his dead saplings with healthy ones. Other farmers did not replanting the jablon seedling because their mortality rate only 1$10 \%$ (Table 4). Most farmers weeded their land every three and six months using machetes, sickles, and hoes to form circle weeds. Mr. Wayan and other farmers on Tetemotaha Village reduced their plants three times in two years. They did not perform pruning because jabon naturally prune themselves.

Typical pests for jabon are caterpillars and stem borers. Pest control was conducted by carrying out both prevention and extermination (Table 5). Mr. Subowo from Wawoone Village and Mr. Abdul from Langonawe Village prevented pests using $1 \mathrm{~kg}$ furadan for every six plants. To control infestation, Tetemoha Village farmer (Mr. Wayan) used chemical insecticide namely Spontan, with a dose of two liters/hectare. 


\subsection{The Growth of White Jabon on Konawe Regency}

Information on the growth of white jabon stands in Konawe Regency is presented in Table 6. The average diameter, stand height, and volume of the six-years-old stand was $25.24 \mathrm{~cm}, 14.81 \mathrm{~m}$, and $219.30\left(\mathrm{~m}^{3} / \mathrm{ha}\right)$, respectively. There were two farmers maintenance the five-years-old stand but the differences of average diameter, stand height, and volume was non-significant. Mr. Abdul's stand had $18.21 \mathrm{~cm}, 11.06 \mathrm{~m}$, and $135.06\left(\mathrm{~m}^{3} / \mathrm{ha}\right)$, while Mr. Subowo's stand had $15.16 \mathrm{~cm}, 14.41 \mathrm{~m}$, and $113.51\left(\mathrm{~m}^{3} / \mathrm{ha}\right)$. The 3.5-years-old stand had the average diameter, height, and stand volume of 12.02 $\mathrm{cm}, 10.99 \mathrm{~m}$, and $74.89\left(\mathrm{~m}^{3} / \mathrm{ha}\right)$. In general, the older stand has a higher volume.

Table 2 Land Preparation and Planting

\begin{tabular}{|c|c|c|c|c|c|c|c|}
\hline $\begin{array}{c}\text { Farmers } \\
\text { Name }\end{array}$ & $\begin{array}{c}\text { Land } \\
\text { Clearing }\end{array}$ & $\begin{array}{l}\text { Cost } \\
\text { (IDR) }\end{array}$ & $\begin{array}{l}\text { Source of } \\
\text { Seedling }\end{array}$ & $\begin{array}{l}\text { Seed } \\
\text { Price } \\
\text { (IDR) }\end{array}$ & $\begin{array}{c}\text { Size of } \\
\text { Seedling } \\
(\mathrm{cm})\end{array}$ & $\begin{array}{c}\text { Size of } \\
\text { Planting } \\
\text { Hole (cm) }\end{array}$ & $\begin{array}{c}\text { Planting } \\
\text { Space } \\
(\mathbf{c m})\end{array}$ \\
\hline Tarigan & All area & - & $\begin{array}{l}\text { Seed and } \\
\text { naturally } \\
\text { grown }\end{array}$ & - & 20 & $10 \times 15 \times 10$ & $4 \times 4$ \\
\hline Abdul & Partially & - & $\begin{array}{l}\text { Seed (other } \\
\text { farmers) }\end{array}$ & 5,000 & 60 & $30 \times 30 \times 40$ & $4 \times 5$ \\
\hline Subowo & All area & 350,000 & Seed (own) & - & 60 & $30 \times 30 \times 40$ & $4 \times 4$ \\
\hline Wayan & All area & 500,000 & Seed (own) & - & 50 & $30 \times 30 \times 30$ & $3 \times 3$ \\
\hline
\end{tabular}

Table 3 Type and Frequency of Fertilizing

\begin{tabular}{lccccc}
\hline \multirow{2}{*}{$\begin{array}{c}\text { Farmers } \\
\text { Name }\end{array}$} & \multirow{2}{*}{ Frequency } & \multicolumn{2}{c}{ Organic } & \multicolumn{2}{c}{ Inorganic } \\
\cline { 3 - 6 } & & Organic & Compost & $\mathbf{N}, \mathbf{P}, \mathbf{K}$ & Urea \\
\hline Tarigan & - & - & - & - & - \\
Abdul & 1 & $0.5 \mathrm{~kg} / \mathrm{plant}$ & - & - & - \\
Subowo & 2 & $0.5 \mathrm{~kg} / \mathrm{plant}$ & - & - & $50 \mathrm{~kg} / \mathrm{ha}$ \\
Wayan & 3 & - & $300 \mathrm{~kg} / \mathrm{ha}$ & $100 \mathrm{~kg} / \mathrm{ha}$ & - \\
\hline
\end{tabular}

Table 4 Maintenance Activities Including Replacing, Fertilizing, and Thinning

\begin{tabular}{|c|c|c|c|c|c|}
\hline \multirow{2}{*}{$\begin{array}{c}\text { Farmers } \\
\text { Name }\end{array}$} & \multirow{2}{*}{$\begin{array}{c}\text { Mortality } \\
(\%)\end{array}$} & \multirow[b]{2}{*}{ Replacing } & \multicolumn{2}{|c|}{ Fertilizing } & \multirow[b]{2}{*}{ Maintenance } \\
\hline & & & Frequency & $\begin{array}{c}\text { Cost } \\
\text { (IDR/ha) }\end{array}$ & \\
\hline Tarigan & 10 & No & - & - & No \\
\hline Abdul & 9 & No & - & - & No \\
\hline Subowo & 1 & No & 1 & 200,000 & No \\
\hline Wayan & 30 & Yes & 2 & $1,000,000$ & $\begin{array}{l}\text { Yes (three times in } \\
\text { two years) }\end{array}$ \\
\hline
\end{tabular}


Table 5 Pest and Disease Control

\begin{tabular}{llccc}
\hline $\begin{array}{c}\text { Farmers } \\
\text { Name }\end{array}$ & \multicolumn{1}{c}{ Pests } & Frequency & \multicolumn{2}{c}{ Protection Method } \\
Prevention & Chemical \\
\hline Tarigan & Stem borers & - & - & - \\
Abdul & Caterpillar & Rare & Furadan $(1 \mathrm{~kg} / 6$ plants $)$ & - \\
Subowo & Caterpillar & Rare & Furadan $(1 \mathrm{~kg} / 6$ plants $)$ & - \\
Wayan & Caterpillar, & Rare & - & Spontan $(2$ \\
& stem borers, & & & liters $/ \mathrm{ha})$ \\
& and wind & & & \\
\hline
\end{tabular}

Table 6 The Growth of White Jabon on Konawe Regency

\begin{tabular}{lcccccccccccc}
\hline $\begin{array}{l}\text { Farmers } \\
\text { Name }\end{array}$ & $\begin{array}{c}\text { Area } \\
(\mathbf{h a})\end{array}$ & $\begin{array}{c}\text { Plot } \\
\text { Number }\end{array}$ & $\begin{array}{c}\text { Plot Size } \\
(\mathbf{h a})\end{array}$ & $\begin{array}{c}\text { Age } \\
(\mathbf{Y r})\end{array}$ & \multicolumn{2}{c}{ Stand Dimension } & \multicolumn{2}{c}{ Increment } & $\begin{array}{c}\text { Hd } \\
(\mathbf{m})\end{array}$ & $\begin{array}{c}\text { Stand } \\
\text { Volume } \\
\left(\mathbf{m}^{\mathbf{3}}\right)\end{array}$ & $\begin{array}{c}\text { Stand } \\
\text { Volume } \\
\left(\mathbf{m}^{3} / \mathbf{h a}\right)\end{array}$ \\
\hline Tarigan & 0.2 & 1 & 0.02 & 6 & 25.24 & 14.81 & 4.20 & 2.46 & 17.87 & 4.39 & 219.30 \\
Abdul & 0.7 & 1 & 0.02 & 5 & 18.21 & 11.06 & 3.64 & 2.21 & 14.14 & 2.70 & 135.06 \\
Subowo & 2 & 4 & 0.08 & 5 & 15.16 & 14.41 & 3.03 & 2.88 & 19.43 & 9.08 & 113.51 \\
Wayan & 2 & 4 & 0.08 & 3.5 & 12.02 & 10.99 & 3.43 & 3.14 & 17.64 & 5.99 & 74.89 \\
\hline
\end{tabular}

Farmers in Konawe Regency were actually entrepreneurs except for Mr. Tarigan, which was a government employee. For the economic reason, they took cultivating as their side job, one of which was jabon farming. This motivation based on the prospect of Jabon in the industrial sector, the relatively short cycle and annual growth in average increment that was relatively high. According to [14] the selling price of processed wood of jabon by collectors in Buton Regency, Kapuntori District,

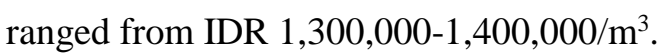

Farmers in Konawe Regency planted jabon without training related to silvicultural techniques. The farmers obtained information about jabon cultivation through books, internet, and experiences of farmers who had already planted jabon. This study was in line with the research of [5] in South Kalimantan who reported that almost all jabon and mahogany farmers learned silvicultural techniques from their own experience and other farmers. Nonetheless, jabon farmers in Konawe Regency were already quite good at applying jabon silviculture techniques, namely seedling procurement, land preparation, planting, replacing, weeding, fertilizing, thinning, and protection from pests and diseases.

The first activity carried out by jabon farmers in Konawe Regency was the procurement of seedlings. Sources of seedling were seeds and naturally-grown seedlings from the tree. Jabon seedlings were obtained from self-germination and purchased from other farmers.

The farmers in Konawe planted jabon seedlings at a size of 20-60 cm. According to [1] good seedlings have a height of $25-30 \mathrm{~cm}$, and [2] stated that seeds with a height of $30-40 \mathrm{~cm}$ and diameter of one $\mathrm{cm}$ are ready to be planted in the field. According to [8] jabon farmers in West Java planted 
seedlings in the range of size 15 to $80 \mathrm{~cm}$. Thus, the size of the seeds planted in Konawe is relatively similar to other regions.

The size of the planting hole varies from $10 \times 15 \times 10 \mathrm{~cm}$ to $30 \times 30 \times 40 \mathrm{~cm}$, while spacing was at a range of 3-4 $\mathrm{m} \times 3-5 \mathrm{~m}$. According to [1], the determination of spacing based on planting purposes; if the planting aimed for carpentry and veneer wood, the minimum spacing was $3 \times 3 \mathrm{~m}$ and planting hole should be at least 30x30x30 cm. According to the research of [2] in South Kalimantan, farmers used a wider spacing of 4-5 $\mathrm{m} \times 4-5 \mathrm{~m}$. The planting hole used by jabon farmers in West Java ranged from $10 \times 15 \times 10 \mathrm{~cm}$ to $40 \times 40 \times 40 \mathrm{~cm}$ with an average spacing of 2-3 $\mathrm{m} \times 2-3 \mathrm{~m}$ [8].

Both basic fertilization and continuation fertilization were conducted by farmers (Table 3). The farmer's comprehension of fertilizing farmers in Konawe Regency had been in line with the statement of [1] that manure and NPK were used as basic fertilizers and urea was used as continuation fertilizer. Based on the results, farmers used organic (manure) and inorganic (N, P, K, and urea) fertilizers. The farmers intended fertilization to stimulate the growth, improve soil structure, and provide nutrient supplies needed by plants. This was in line with the opinion of [2] who stated that fertilizing jabon aims to obtain optimal growth on infertile land.

Maintenance activities were replanting, weeding, and protection from pests and diseases. Replacement activities were carried out on dead or stunted seedlings. Mr. Wayan was the only farmer conducted this activity due to his stand mortality was $30 \%$. The death rate was suspected to be caused by seed genetic factors such as the origin of seeds and the quality of the parent tree. According to [8] seeds with good quality greatly influence plant growth and plant mortality. Jabon seeds grown by Mr. Wayan sourced from forests and were taken randomly without considering the quality of the parent tree.

The four farmers in Konawe conducted weeding once every three and six months. Weeding aimed to eliminate competing vegetation around the stand. According to [1], if disturbing vegetation was allowed to grow, it would be a competitor on the light, water, nutrients, and space provided to supply jabon growth. Weeding should be done during the first few years until the tree canopy was full [2].

Thinning aims to eliminate plants with poor quality. Farmers in Tetemota Village, namely $\mathrm{Mr}$. Wayan, conducted three thinnings in the last two years by cutting down dried or dead jabon trees for firewood. Refers to [2] thinning on the spacing of $3 \times 3 \mathrm{~m}$ to be conducted at the age of two, four and seven years.

Farmers in Konawe carried out prevention and eradication pests and diseases. Furadan was used as a prevention, while Spontan was used to exterminate the pest. The insecticide was applied by spraying 
it to jabon plants. According to [8] that the farmers in West Java conducted pest prevention on jabon plants using Furadan with doses ranged from 50-200 g/plant, and exterminated pest using insecticides.

Based on the data in Table 6, the stand volume per ha was different for each stand. One of the factors that influence variations in stand volume per ha was the plant age. We suspected the difference in diameter and height of trees between Mr. Abdul and Mr. Subowo's stand was caused by spacing. Both stands were at the same age. The wider space tended to produce trees with larger diameters, but have shorter branch-free height [17]. Another factor that was thought to affect the growth of Jabon was the site conditions. According to [8] that site conditions including soil fertility had a significant impact on the growth of jabon in community forests in West Java.

In general, the highest average diameter and height found in the stand owned by Mr. Tarigan. However, the highest increment was found in Tetemotaha Village. The high increment in Mr. Wayan stand was suspected due to intensive fertilization. According to [10] that fertilization and land management had an effect on growth. Mr. Tarigan obtained the highest average diameter, height, and volume, despite not conducting intensive silvicultural techniques. We suspected that the site quality was excellent. Historically, Mr. Wayan's stand was a former paddy field while Mr. Tarigan's was a forest.

The average diameter and height of the less than 5-year-old jabon tree (Mr. Wayan) in Konawe Regency was lower than that of [2] in South Kalimantan and [8] in West Java. In South Kalimantan, the jabon stands with less than 5-years-old had the average diameter variation of 6.0-16.4 cm, the maximum diameter of $25.3 \mathrm{~cm}$, the average height of 4.1-14.6 m, and the maximum height of $17.1 \mathrm{~m}$. According to [8] who studied of jabon stands in West Java and resulted in lower diameter and average height but the higher diameter and maximum height compared to that of [2], despite their similar age. However, the maximum jabon plant in Konawe was greater than both sites: $17.64 \mathrm{~m}^{3}$. We suspected it due to different condition of sites and the lack of application of silvicultural techniques at the study site. According to [16] that the growth of jabon stand will increase if the application of cultivation techniques components was improved.

\section{Conclusion}

Based on the outcome of the study, it was concluded that the silvicultural techniques applied by white jabon farmers in Konawe Regency are still inadequate and can imply the growth of white jabon in four areas in Konawe Regency. The growth of white jabon plants was moderate compared to other studies. 


\section{REFERENCES}

[1] I. Mansur and F.D. Tuheteru, Jabon Wood, Jakarta, Penebar Swadaya, 2010.

[2] H. Krisnawati, M. Kallio, and M. Kanninen, Anthocephalus cadamba Miq: Ecology, Silviculture dan Productivity, Center for International Forestry Research, Bogor, 2011.

[3] J.E. Halawane, H.N. Hidayah, and J. Kinho, Prospects for the Development of Red Jabon Anthocephalus macrophyllus (Roxb.) Result of the Solutions of Future Wood Needs, Forestry Research and Development Agency Forestry Research Institute Manado, Menado, 2011.

[4] D.J. Sudrajat, "Population Diversity, Provenance Test and Adaptation of Jabon (Neolamarckia cadamba (ROXB.) BOSS)," M.S thesis, Bogor Agricultural University, Bogor, 2015.

[5] M.H. Kallio, H. Krisnawati, D. Rohadi, and M. Kanninen, "Mahogany and Kadam Planting Farmers in South Kalimantan: The Link between Silvicultural Activity and Stand Quality," Small-Scale Forestry, pp. 1-18. 2011.

[6] M. Yulianti, "Preparation of Local Volume Tables of Jabon (Anthocephalus cadamba) in the Community Forest of Punggelan Village, Punggelan District, Banjarnegara, Central Java," Tekno plantation forest, vol. 5, no. 2, 2012.

[7] T. Amelia, "Diversity of Arbuscular Mycorrhizal Fungi (FMA) under the jabon plant stand (Anthocephalus cadamba Miq.) In Pemalang Central Java," M.S thesis, Bogor Agricultural University, Bogor, 2013.

[8] N.N. Siddiqah, "Feasibility Evaluation of Investment in Jabon Community Forest in Brebeg Village, Jeruklegi District, Cilacap District," M.S thesis, Bogor Agricultural University, Bogor, 2014.

[9] S. Jinwon, "Silvicultural Practices and Growth of Jabon Tree (Anthocephalus cadamba Miq.) In Community Forest, West Java, Indonesia," M.S thesis, Bogor Agricultural University, Bogor, 2013.

[10] L. Abdulah, L. Mindawati, A.S. Kosasih, and Darwo, "Evaluation of Initial Growth of Jabon (Neolamarckia Cadamba Roxb) in Community Forests," Journal of Plantation Forestry Research, vol. 10, no. 3, pp. 119-128. 2013.

[11] L. Fauziah, "Diversity of Arbuscular Mycorrhizal Fungi Understorey the Agroforestry Stand of Jabon (Anthocephalus cadamba Miq.) In Purwakarta, West Java," M.S thesis, Bogor Agricultural University, Bogor, 2013.

[12] M. Siarudin and Y. Indrajaya, "Equations of Jabon Allometrics (Anthocephalus cadamba Miq.) For Estimating Biomass Above Soil in Pakenjeng District Community Forest Garut Regency," Plantation research journal, vol. 11, no. 1, pp. 1-9. 2014.

[13] A.P. Dewi, "Diversity of Arbuscular Mycorrhizal Fungi Understorey on Jabon (Anthocephalus cadamba) in Madiun, East Java," M.S thesis, Bogor Agricultural University, Bogor, 2014.

[14] R. Sari, "Marketing Study of Jabon Wood (Anthocephalus cadamba Miq.) Community Forest Products Wambulu Village Kapuntori District," M.S thesis, Halu Oleo University, Kendari, 2013.

[15] N. Marnia, "Identification of Lower Plants in Jabon Stands (Anthocephalus cadamba Miq.) In the Community Forest of Wawoone Village, Wonggeduku Subdistrict, Konawe District," M.S thesis, Halu Oleo University, Kendari, 2015.

[16] A.P.P. Hartoyo, "Techniques and Costs of Cultivating Jabon (Anthocephalus cadamba Miq.) by Community Wood Farmers," M.S thesis, Bogor Agricultural University, Bogor, 2013. 
[17] I. Wahyudi, D.K.D. Sinaga, Muhran, and L.B. Jasni, "Physical Spacing Effect on Tree Growth and Several Properties of Faster -Grown Teak Wood," Jurnal Ilmu Pertanian Indonesia vol. 19, no. 3, pp. 204-210. 2014. 